Article

\title{
Rising Inequality and Entrepreneurship during Economic Downturn: An Analysis of Opportunity and Necessity Entrepreneurship in Spain
}

\author{
María-Teresa Aceytuno *, Celia Sánchez-López and Manuela A. de Paz-Báñez ${ }^{\mathbb{D}}$ \\ Facultad de Ciencias Empresariales, University of Huelva, 21004 Huelva, Spain; celia@ole.uhu.es (C.S.-L.); \\ depaz@uhu.es (M.A.d.P.-B.) \\ * Correspondence: maria.aceytuno@dege.uhu.es
}

Received: 29 April 2020; Accepted: 27 May 2020; Published: 3 June 2020

\begin{abstract}
There is a consensus among researchers that one of the most important effects of the recent economic downturn that started in 2009-also known as the Great Recession-in Spain has been rising income inequality. In this context, researchers are concerned about the effects of inequality on the economy, and this concern is even more marked now, when the world is facing a new crisis that seems the equal of, or even more devastating than the last Great Recession as a consequence of Covid-19. Nevertheless, there is a lack of studies which consider the effects of inequality on entrepreneurship. This paper aims to contribute to a deeper understanding of the relationship between inequality and entrepreneurship in the context of an economic downturn. We focus on the 17 autonomous communities in Spain during the Great Recession (2007-2013). Using unbalanced panel data, we study the effect on entrepreneurial activity, differentiating between total, necessity- and opportunity-driven entrepreneurship. The contribution of this paper is twofold. First, our results offer new empirical evidence concerning the relationship between growing inequality and entrepreneurial activity, showing significant differences from results in the existing literature. Second, we explain how, in a recessionary context of highly restricted financial resources, inequality can negatively affect total, necessity- and opportunity-based entrepreneurship, preventing a large part of the population from engaging in this activity.
\end{abstract}

Keywords: income inequality; Spanish regions; entrepreneurship; entrepreneurial motivation; economic crisis

\section{Introduction}

Over the past three decades, the vast majority of OECD countries have seen a rise in income inequality, and there is a growing interest among policy makers towards the socio-political consequences of this trend. A range of academic research shows that growing inequality may have negative effects on society such as social resentment, populist and protectionist sentiments, and political instability $[1,2]$. Although some researchers consider that a certain degree of inequality stimulates economic activity, increasing inequality also has wider economic impacts, acting as a drag on further growth, reducing access to education and limiting the expansion of demand and consumption [1-3].

There are reasons to believe that entrepreneurial activity and economic inequality are linked. The distribution of financial resources within the population accounts for economic inequality and, at the same time, may lead to an increase in entrepreneurial activity. There is a wide literature that recognizes the importance of institutional factors as determinants of entrepreneurship, considering both formal and informal institutions [4,5]. Formal institutions are examined in comparative entrepreneurship research chiefly in terms of institutional economics, while in the case of informal institutions the 
prevalent approaches are cultural sociology and cross-cultural psychology [4]. Among the institutional factors related to inequality which have been studied as determinants of entrepreneurship are capital markets, wealth transfer and labor market policies [6,7].

In a similar fashion, a growing number of recent works delve into the consequences of rising economic inequality for entrepreneurial activity [6-10]. Braggion et al. [7] focus on the effects of income inequality on entrepreneurs' financial constraints, finding empirical evidence that entrepreneurs in areas of inequality are less likely to apply for loans from fear of being turned down, and instead rely more on their own equity to set up a business. The authors conclude that wealth inequality is a relevant factor to be taken into account when considering the financial constraints on entrepreneurs.

Pathak and Muralidharan [10] analyze the impact of economic inequality on entrepreneurship, finding different effects on social and commercial entrepreneurship. The authors regard income inequality and income mobility as conditions of formal regulatory institutional frameworks. Income inequality is made more likely by institutional voids, that is, failure of governments to provide sufficient mechanisms for adequate income distribution in society; income mobility is a condition under which subsequent generations can improve their economic status, regardless of that of their parents, and is favored by conditions of institutional support. Their results show how different institutional pressures have different effects on entrepreneurship [10].

Other studies explore the effects of wealth inequality in terms of entrepreneurial motivation, whether necessity- or opportunity-driven. Whilst Lippmann et al. [6] find an overall positive relationship between income inequality and entrepreneurial activity across the set of countries in their study, they also note the divergence between necessity- and opportunity-driven entrepreneurship, finding a positive relationship for the former but an inverted U-shaped relationship for the latter. Similar results are obtained by Ragoubi and El Harbi [9], who analyze the relationship between entrepreneurship and income inequality for a set of high, medium and low income countries, and likewise find evidence for the existence of the U-shaped relationship mentioned above. Finally, Xavier-Oliveira et al. [8] examine the effect of wealth inequality on entrepreneurial activity with respect to human and financial capital. This study finds that with regard to entry into necessity entrepreneurship, increasing inequality brings about a decrease in the deterrent occasioned by the demands of financial and human capital investment, whereas with regard to entry into opportunity entrepreneurship, it finds statistical support for the augmented relevance of financial capital.

Scholars have also suggested the reverse relationship, whereby entrepreneurship may be a driving force for economic inequality rather than an outcome $[6,11,12]$. Recent studies focus on how the rise in self-employment and small business ownership in recent decades could be contributing to the upward trajectory of income inequality. Following this idea, Halvarsson et al. [13] find evidence for the contribution of self-employment to income dispersion using microdata from Sweden. Lewellyn [14] analyzes the complex relationship between income inequality and entrepreneurial activity from a systemic perspective using qualitative techniques. Atems and Shand [15] investigate if entrepreneurship impacts inequality, finding empirical evidence of a positive correlation. Nevertheless, others [12] point out the influence of both institutional and social factors on achieving a reduction in inequality through entrepreneurship.

Recent research highlights the complexity of the relationship between entrepreneurship and economic inequality. Scholars point out the importance of further research, given that the question of causality is not clear and entrepreneurship is potentially endogenous in that inequality may also affect the level of entrepreneurship [13,15]. Furthermore, recent research also highlights the importance of the institutional environment in the relationship between entrepreneurial activity and inequality [12].

This paper aims to contribute to this nascent literature on economic inequality and entrepreneurship. Our general research question aims to explore the effect of income inequality on entrepreneurial activity in the context of an economic downturn. To do so, we developed an analysis of the effect of rising economic inequality on entrepreneurial activity, with a focus on the seventeen autonomous communities making up Spain during the Great Recession. We use data 
from Global Entrepreneurship Monitor (GEM) to differentiate between total, necessity-driven and opportunity-driven entrepreneurial activity.

To the best of our knowledge, none of the few studies which consider the impact of economic inequality on entrepreneurship focuses on a context of economic downturn or differentiates the motivations for entrepreneurship. Indeed, this study provides new statistical evidence about the relationship between economic inequality and entrepreneurial activity, but above all it provides novel insights into the mechanisms through which inequality can affect entrepreneurial activity in the context of an economic downturn. This particular emphasis is of particular interest as the results of our analysis show significant differences to some of those in the current literature [6,8,9], although they corroborate with the results of others [7]. We find a negative relationship between income inequality and both opportunity- and necessity-driven entrepreneurship. Drawing on the literature [7,16], we argue that rising wealth inequality across the Spanish regions during the Great Recession led to increasing financial constraints on entrepreneurs.

In this context, our contribution to the field of study is twofold. First, the theoretical contribution of the paper is to explain how growing inequality in a downturn negatively affects entrepreneurial activity by increasing the financial constraints that entrepreneurs have to face to develop their business; and second, we present empirical evidence to support this negative relationship.

The paper is organized thus: following this introduction, Section 2 sets out the relevant theory and the hypothesis derived from it. Section 3 presents the empirical analysis and results, which are then discussed in Section 4. The paper finishes with a brief conclusion.

\section{Theory and Hypothesis}

The relationship between socio-economic context and entrepreneurial activity has received considerable attention in the literature (see [17] for a detailed review). However, due to the complexity of this relationship, there is evidence of both positive and negative effects on entrepreneurship.

After the Great Recession, recent studies have analyzed the effect of the recessionary context on entrepreneurial intention, finding empirical evidence that the economic crisis impacted negatively on potential entrepreneurs' assessment of environmental conditions, subsequently shaping his/her intention to create a new venture $[18,19]$. Recent studies focusing on entrepreneurship in Spain or Greece during the Great Recession points out how a recessionary context shapes other aspects of entrepreneurial process such as venture's success or failure [20,21], firm behavior [22] or entrepreneurs' perceptions [23], for both commercial and social entrepreneurship [24].

The aftermath of the Great Recession has been characterized by rising inequality between and within regions and countries, which is considered to have an effect on levels of entrepreneurship. According to Lippmann et al. [6], if certain types of entrepreneurial activity require financial resources, then the unequal distribution of these could act as a limiting factor. Alternatively, if inequality limits individuals' opportunities to participate in the formal labor market, they pursue self-employment as a last resort.

Nevertheless, the relationship between economic inequality and entrepreneurship is complex. On the one hand, inequality has been considered as a contextual barrier for economic activity and consequently for enterprise creation, as it contributes to relatively lower levels of trust, skills, social mobility and other social problems [8]. The consolidation of inequality may lead to a lack of opportunities and in this context, the foundation of new businesses contributes to the reproduction of social and economic inequalities. Furthermore, it may narrow the range of startup types in a society, thus limiting organizational and industrial diversity [6].

On the other hand, entrepreneurship has traditionally been considered as a potential route for moving up the socioeconomic ladder. As noted in the literature [6], the origins of this idea can be traced back to the spread of the industrial revolution to other western capitalist societies in the 19th century, which allowed immigrants and children of the working class to become prosperous business owners. Nevertheless, recent studies from advanced economies show that social mobility may decrease as 
inequality increases, in a phenomenon known as the "Great Gatsby Curve" [25]. This could be due to the strong incentives of richer individuals to preserve inequalities by regressive taxation, limits to education or augmented entry barriers for new firms [8].

Researchers agree that economic inequality may lead to an uneven distribution of financial resources, influencing an individual's likelihood of becoming a nascent entrepreneur. Nevertheless, this influence can vary according to the entrepreneur's motivation, which can be broadly differentiated into two types: opportunity entrepreneurship and necessity entrepreneurship. While necessity entrepreneurs are mostly driven by push factors rooted in the primary need to survive, opportunity entrepreneurs are driven by intrinsic motivations, such as the need for achievement or opportunity recognition $[6,8,26]$. Compared to necessity entrepreneurs, opportunity entrepreneurs usually prepare their entry into self-employment better and create their business in their field of expertise. As a result, they present longer survival rates and have a differential impact on economic growth and job creation $[17,27]$.

\subsection{Hypothesis}

The aim of this paper is to contribute to the literature about the complex relationship between economic inequality and entrepreneurship by focusing on a recessionary context. To do this, we set three hypotheses which explain how rising economic inequality can influence total entrepreneurship, necessity entrepreneurship and opportunity entrepreneurship in a context of economic crisis.

In general, it can be argued that entrepreneurship is likely to be spurred by higher levels of inequality [26]. Thus, countries with higher levels of wealth inequality tend to have higher rates of entrepreneurship [6].

Davidsson et al. [28] analyzes the effects of external conditions—external enablers—on entrepreneurial action and outcomes. The authors provide a framework to study how external changes-such as rising inequality - trigger and facilitate entrepreneurial activity. In this regard, as suggested above, the presence of rising inequality could be considered as an external enabler of new venture creation, but its effect is moderated by context and also depends on agents' characteristics. Thus, both context and agent motivation should be taken into account to hypothesize the relationship between rising economic inequality and entrepreneurship.

Consonant with this framework, recent research analyzes the extent to which income inequality and income mobility might affect social entrepreneurship. As mentioned in the introductory section, Pathak and Muralidharan (2018) empirically test institutional conditions of income inequality (created by institutional voids) and income mobility (created by conditions of institutional support) for their effect on the likelihood of social entrepreneurship finding that country-level income inequality increases it, while income mobility has the contrary effect. Furthermore, the authors find that income mobility has a negative moderation effect on the influence of income inequality on social entrepreneurship [10].

The role of economic inequality as an external enabler can be further discussed in terms of the effect of financial constraints in the context of an economic crisis such as the Great Recession in Spain (2008-2013). As noted in the literature review, a recessionary context might be considered as a barrier to entrepreneurship. There is agreement among researchers that the economic context is directly linked to entrepreneurial intentions [18] although there is no agreement about its effect (see [18] for a literature review on this topic). While part of the literature considers recession as fertile ground for new opportunities - a positive pull effect-other researchers point out that economic recession can be unfavorable to entry into entrepreneurship because, compared to times of economic prosperity, it presents a range of barriers, such as lower customer demand, lower expected return and less availability of finance $[19,29]$.

The Great Depression has shown that while some regions suffered heavily during recession, others exhibited considerable economic resilience to recessionary shocks. Recent literature has focused on the factors that cushion the effects of recessions on different regions. While one line of research has focused on the protective effects of the local economic infrastructure (for instance, [30,31], 
others have developed alternative explanations. One such explanation considers that variations in the macro-psychological make-up of different regions can help explain localized resilience to economic adversity, over and above the role played by structural economic factors [32].

Gonzalez-Pernía et al. [33] analyzes the case of the Spanish regions during the period 2007-2010 and shows that entrepreneurship shrank during the economic downturn suggesting a pro-cyclical trend. They consider that a weaker perception of business opportunities by individuals as a result of the shake-out explains, to a large extent, the lower propensity to create firms during economic recession.

One possible explanation for this phenomenon is suggested by the fact that the decrease in entrepreneurial activity in European territories was more pronounced in regions where access to finance was more difficult (i.e., southern EU) [34]. Researchers agree that one major negative impact of the Great Recession on business start-ups was the increased difficulty in accessing finance from banks, venture capitalists or angel investors [7,29]. Examining the effect of inequality on entrepreneurship during the subprime crisis in the United States, Braggion et al. [7] conclude that, holding everything else constant, in more unequal counties, startups tended to be most frequently financed with entrepreneurs' own resources. This scarcity of financial resources for entrepreneurship during the crisis was particularly marked in Spain, as the bursting of the property bubble caused grave problems for saving banks, leading to a severe credit crunch. The degree of severity can be measured by the 'credit gap', an indicator used by the Bank of Spain, which measures the evolution of the credit-to-GDP ratio against the historical average of this relationship. The 'gap' was at -57.7 percentage points in September 2015 (meaning that credit-to-GDP was that far below the long-term average), its lowest level since 1970.

In this context, higher levels of inequality may drastically reduce the financial capital available to a large part of population. Large numbers in Spain faced great difficulty in making ends meet, and needed to seek support from other family members [35]. In a credit crunch, home equity and other forms of personal wealth become significant potential sources of investment for business creation $[7,29]$. Nevertheless, potential entrepreneurs, facing a minimum financial investment and lacking access to bank credit, are often unable or unwilling to invest their own resources, and hence entrepreneurial activity is likely to decline. For their part, some entrepreneurs, given their incapacity to face the minimum financial requirements to begin a business, could feel pushed to become part of the informal economy.

In view of this, we will consider that the relationship between income inequality and entrepreneurial activity will be negative in a context of economic recession, given the significant financial constraints resulting from a crisis that can be a barrier to entrepreneurial ventures.

Hypothesis (H1). During an economic recession, there will be a negative relationship between income inequality and total entrepreneurial activity.

Drawing on the external enablers framework [28] and considering that the financial investment required to start a business differs with the entrepreneur's motivation, we set different hypotheses for opportunity entrepreneurship and necessity entrepreneurship.

\subsubsection{Opportunity Entrepreneurship}

The empirical evidence for the relationship between inequality and opportunity-driven entrepreneurship is not clear. Reynolds et al. [26] show that opportunity entrepreneurship has a curvilinear relationship with inequality, peaking at an intermediate level of income inequality. There are two possible explanations for this relationship.

First, as inequality increases, some segments of the population have surplus capital to invest in new ventures, resulting in an increase in opportunity entrepreneurship. Rising inequality indicates that elites have begun to accumulate a disproportionate share of resources that they can use to initiate economic development [6,8]. 
Second, higher levels of inequality may drastically reduce the financial resources for a large share of population, who would then be unwilling to pursue opportunity entrepreneurship, as capital investment tends to play a more important role in this type of entrepreneurship $[8,36]$. If large numbers of the population suffer financial constraints, the negative influence of inequality over opportunity entrepreneurship might be higher. Thus, given the severe financial constraints in Spain during the Great Recession, we consider there to be a negative relationship between economic inequality and opportunity entrepreneurship [7].

Hypothesis (H2). During an economic recession, there will be a negative relationship between income inequality and opportunity entrepreneurship.

\subsubsection{Necessity Entrepreneurship}

The empirical literature about the relationship between inequality and necessity entrepreneurship show that they are positive correlated. Countries with higher levels of inequality have larger poor and low income populations [6]. For such groups, which typically also have low levels of education and little access to sources of power and influence, necessity entrepreneurship might be the most readily available option for earning a living. In a context of rising inequality, the proportion of the population with relatively lower financial capital resources increases, and more individuals are willing to fulfill push motivations towards entrepreneurship. The urgency of getting a source of income increases with the level of inequality, particularly for individuals in the lower socioeconomic strata [8].

It is also pointed out that rising inequality can reduce the percentage of people with relatively higher financial capital, as wealth becomes concentrated in the hands of fewer individuals [8]. Thus, the richest sector of the population may become richer as inequality increases and individuals with abundant financial capital resources can perceive themselves as being worse off in comparison. This could drive them towards entrepreneurship in order to add to their income and gain a better position in society. This kind of entrepreneurship is likely to stem from push rather than pull factors [8].

Nevertheless, recent studies focusing on Spain during the Great Recession show that entrepreneurship is pro-cyclical and declines during periods of economic shrinkage [33]. Necessity entrepreneurship, restricted borrowing and reduced consumer demand, together with rising inequality, could be important deterrents to entrepreneurship during the economic downturn, even for those activities with lower financial requirements, although there is no specific evidence of it. Moreover, as suggested above, some entrepreneurs could be pushed into the informal economy rather than formal entrepreneurship. Consequently, we consider there to be a negative relationship between economic inequality and necessity entrepreneurship.

Hypothesis (H3). During an economic recession, there will be a negative relationship between income inequality and necessity entrepreneurship.

\section{Materials and Methods}

\subsection{Income Inequality in Spain and the Great Recession}

Peripheral countries in Europe, such as Portugal, Italy, Ireland, Greece, and Spain, have been strongly affected by the recent financial crisis. Some of the consequences include a rise in the unemployment rate, limited access to financing, and a decline in the growth of gross domestic product (GDP) [33]. The scope and importance of the consequences of the economic recession on the seventeen Spanish regions can be studied in terms of GDP per capita and economic inequality (using the Gini index) (Table 1). The already uneven distribution of wealth in Spain continued during the Great Recession and indeed increased in all regions [35] with an average increase of $8.64 \%$ on the Gini index between 2008 and 2012. 
Table 1. Evolution of GDP per capita and Gini index across the 17 Autonomous Regions of Spain.

\begin{tabular}{cccccccc}
\hline Region & $\begin{array}{c}\text { GDPpc } \\
\mathbf{2 0 1 3}\end{array}$ & $\begin{array}{c}\text { GDPpc } \\
\mathbf{2 0 0 8}\end{array}$ & Gini 2012 & Gini 2008 & $\begin{array}{c}\text { Ranking } \\
\mathbf{2 0 1 2}\end{array}$ & $\begin{array}{c}\text { Ranking } \\
\mathbf{2 0 0 8}\end{array}$ & $\begin{array}{c}\text { Var 12-08 } \\
\mathbf{( \% )}\end{array}$ \\
\hline Andalucía & 16,379 & 18,625 & 0.3443 & 0.3157 & 3 & 3 & 9.05 \\
Aragón & 24,417 & 26,650 & 0.3311 & 0.2704 & 5 & 13 & 22.44 \\
Asturias & 19,445 & 22,336 & 0.3162 & 0.2646 & 11 & 16 & 19.49 \\
Baleares & 22,924 & 25,717 & 0.3223 & 0.2912 & 8 & 10 & 10.66 \\
Canarias & 18,761 & 21,186 & 0.3465 & 0.3119 & 2 & 4 & 11.07 \\
Cantabria & 19,965 & 122,850 & 0.3198 & 0.2662 & 10 & 15 & 20.12 \\
Castilla y León & 20,688 & 22,421 & 0.3062 & 0.3009 & 14 & 7 & 1.75 \\
Castilla La Mancha & 17,557 & 19,697 & 0.3630 & 0.3227 & 1 & 1 & 12.48 \\
Catalonia & 25,945 & 28,332 & 0.3124 & 0.2964 & 13 & 8 & 5.40 \\
C.Valenciana & 19,176 & 21,878 & 0.3328 & 0.3030 & 4 & 6 & 10.14 \\
Extremadura & 15,280 & 16,633 & 0.3200 & 0.3170 & 9 & 2 & 0.93 \\
Galicia & 19,508 & 21,226 & 0.3137 & 0.2743 & 12 & 12 & 14.39 \\
Madrid & 30,188 & 32,155 & 0.3248 & 0.3101 & 6 & 5 & 4.74 \\
Murcia & 18,122 & 20,354 & 0.3054 & 0.2936 & 16 & 9 & 4.03 \\
Navarra & 27,442 & 30,128 & 0.2781 & 0.2604 & 17 & 17 & 6.79 \\
País Vasco & 28,858 & 31,243 & 0.3062 & 0.2688 & 15 & 14 & 13.91 \\
La Rioja & 23,726 & 25,986 & 0.3227 & 0.2768 & 7 & 11 & 16.58 \\
SPAIN & 22,014 & 24,275 & 0.3359 & 0.3092 & & & 8.64 \\
\hline
\end{tabular}

Sources: GDPpc from INE (Spanish Statistics Institute); Gini index and evolution [37], calculated from micro data from living conditions survey.

In terms of individual regions, this increase was distributed unevenly. Thus, while the Gini index rose by around 20\% in the regions of Aragón, Cantabria and Asturias, it increased by around $2 \%$ in Extremadura and Castilla-León [37]. This generalized but uneven increase in inequality can be visualized in terms of changes to the rank position of each region on a hypothetical Gini league table. Hence, Extremadura, which underwent a lower rate of increase between 2008 and 2012 relative to other regions, drops down the table from its position as one of the most economically unequal regions (specifically from 2nd to 9th position), as does Murcia (from 9th to 16th). By contrast, other regions which experienced high rates of increase in inequality include Aragón (from 13th to 5th), Asturias (from 17th to 11th) and Cantabria (from 15th to 10th) (Table 1). In summary, the outbreak of the Great Recession aggravated the situation of inequality in the Spanish regions, as the precarious situation of the labor market and an ineffective redistribution of the tax-benefit system dramatically deteriorated [35].

The evolution of entrepreneurial activity throughout Spain also changed drastically over the period of the Great Recession. Total entrepreneurial activity (TEA)—-that is, the percentage of population from 18 to 64 years old involved in business-fell from $7.6 \%$ in 2007 to and $5.4 \%$ in 2010, passing through about $5 \%$ in 2009 (Figure 1).

On analyzing the profile of those involved in the initial phases of entrepreneurial activity, it is important to note that $70.2 \%$ of TEA in Spain in 2016 related to opportunity driven initiatives, while $26 \%$ corresponded to necessity driven initiatives resulting from a lack of opportunities in the labor market. Before the Great Recession, the percentage of opportunity entrepreneurship was above $80 \%$, but necessity motivation drastically increased during the crisis (see Figure 1). 


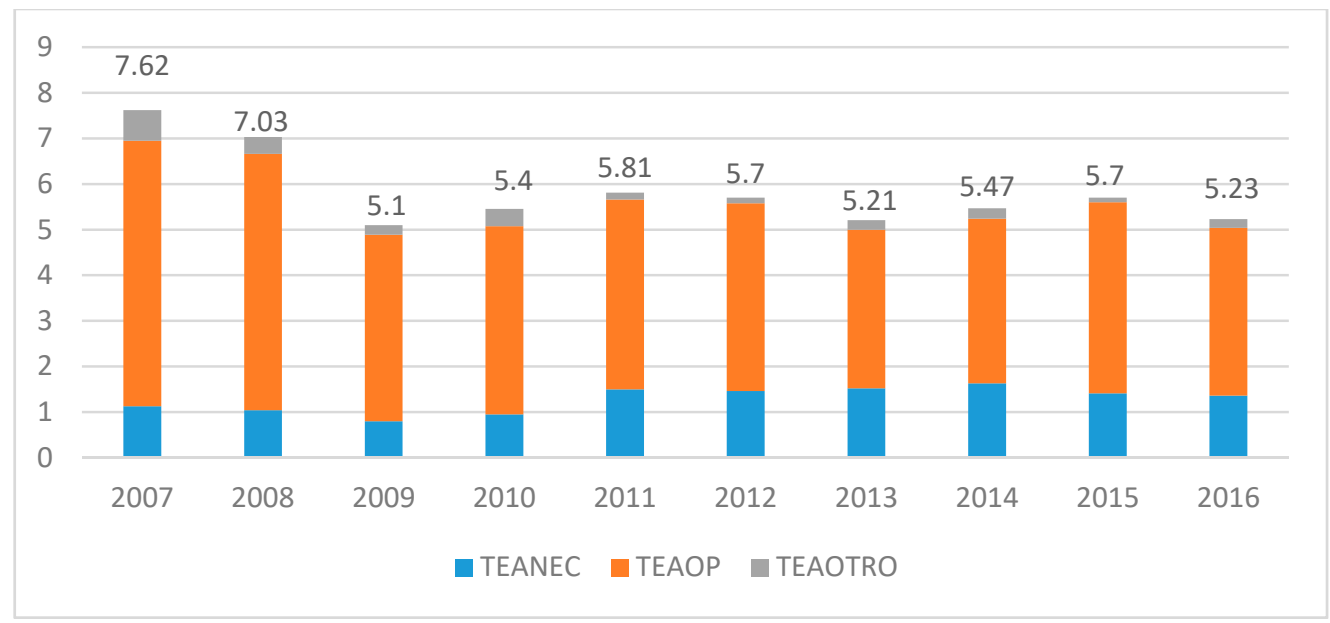

Figure 1. Evolution of Total entrepreneurial activity (TEA) and entrepreneurial motivation in Spain. TEANEC Total Entrepreneurial Activity (Necessity-driven), TEAOP Total Entrepreneurial Activity (Opportunity-driven), TEAOTRO Total Entrepreneurial Activity (Other motivation), Source: Authors' own elaboration from GEM data [38].

\subsection{Data and Methods}

To test the stated hypothesis, we conducted a multiple linear regression. The dataset was an unbalanced panel dataset that combined measures of region-level entrepreneurial activity and financial support collected from the GEM Spain (Data available at the GEM Spain website: http: //www.gem-spain.com/.), with measures of region-level income inequality (OECD, Regional Statistics), GDP per capita and labor market indicators (Eurostat). Both GDP per capita and labor market indicators were variations from the previous year. Our dataset covered the period 2007-2013. Ceuta and Melilla were excluded from the analysis since they caused distortions in the results (Ceuta and Melilla are Spanish cities located in North Africa. They formed part of the region of Andalusia until 1995, when they were declared autonomous cities. Set alongside other Spanish regions their population is very small (around 84,000, compared to the 300,000 of La Rioja, the least populous of the autonomous communities). This disparity led to significant fluctuations in entrepreneurial rates according to GEM).

We developed four models to test each hypothesis. Models were estimated using a linear regression model (OLS) controlling for fixed individual effects using within model. The software used was RStudio, PLM package [39]. The general tested equations for fixed effects are:

$$
Y_{i, t}=\beta_{i} X_{i, t}+\alpha_{i}+e_{i, t}
$$

where: $Y_{i, t}$ is the dependent variable (tea, teaop, teanec); $\alpha_{i}$ represents all the stable characteristics of the regions; $X_{i, t}$ represents the vector of independent variables; $\beta_{i}$ are the coefficients; and $e_{i, t}$ is the error term.

The fixed effect panel model is commonly used for assessing the determinants of entrepreneurship. Fixed effects underline disparities between regions. We then tested a simple fixed effect model, but in accordance with the literature on panel data models, several trials were conducted in order to select the model that best fitted the analysis $[40,41]$. Both the Breusch-Pagan and F test for individual effects results indicated that there were fixed effects that recommended the use of a within model instead of pooling and random models.

While predictor variables remained the same, the dependent variable was different in each model. Multicollinearity was controlled for and no problems were found in this respect. Correlations between the variables used in the analysis are reported in Tables 2 and 3 given a descriptive analysis. 
Table 2. Descriptive statistics and description of the variables.

\begin{tabular}{|c|c|c|c|c|c|c|c|c|}
\hline & Statistics & Mean & Min. & Max. & S.D. & Exp.sign & Definition and Description & Sources \\
\hline (1) & TEA & 5.46 & 1.50 & 9.0 & 1.71 & & $\begin{array}{l}\text { Percentage of the population between } 18 \text { and } 64 \text { years old who are either } \\
\text { in the process of starting a business (nascent entrepreneurs) or the } \\
\text { owner-manager of a new business which is less than } 42 \text { months old. }\end{array}$ & GEM \\
\hline (2) & TEAOP & 4.08 & 1.49 & 7.23 & 1.46 & & $\begin{array}{l}\text { Percentage of the population who are involved in an early-stage } \\
\text { business (either as a nascent entrepreneur or an owner-manager of a } \\
\text { new business) motivated by the recognition of an } \\
\text { entrepreneurial opportunity }\end{array}$ & GEM \\
\hline (3) & TEANEC & 1.14 & 0.21 & 2.50 & 0.45 & & $\begin{array}{l}\text { Percentage of the population who are involved in early-stage business } \\
\text { (either as a nascent entrepreneur or an owner-manager of a new } \\
\text { business) motivated by necessity }\end{array}$ & GEM \\
\hline (4) & GINI & 0.35 & 0.26 & 0.42 & 0.02 & $(-)$ & Gini index at the regional level & OECD \\
\hline (5) & Employment & 1.88 & -9.61 & 6.76 & 3.20 & $(+)$ & $\begin{array}{c}\text { Interannual variations in the number of employed people at the regional } \\
\text { level (see Eurostat for further definitions) }\end{array}$ & Eurostat \\
\hline (6) & Part-time empl. & 2.27 & -8.18 & 17.3 & 5.42 & $(+/-)$ & $\begin{array}{l}\text { Interannual variations in the number of part-time employed people at } \\
\text { the regional level. }\end{array}$ & Eurostat \\
\hline (7) & Unemployment & 20.4 & -13.4 & 82.1 & 22.8 & $(+)$ & $\begin{array}{l}\text { Interannual variations in the number of unemployed people at the } \\
\text { regional level. }\end{array}$ & Eurostat \\
\hline (8) & GDPpc & 5.46 & 1.50 & 9.0 & 1.71 & $(+/-)$ & Interannual variations in GDP per capita at the regional level & INE \\
\hline (9) & $\begin{array}{l}\text { Population } \\
\text { density }\end{array}$ & 4.08 & 1.49 & 7.23 & 1.46 & $(+/-)$ & Population density by NUTS 2 region (inhabitants per square kilometer) & Eurostat \\
\hline (10) & $\begin{array}{l}\text { Financial } \\
\text { support }\end{array}$ & 2.33 & 1.74 & 3.87 & 0.39 & $(+)$ & $\begin{array}{l}\text { Measure of availability of financial resources—equity and debt—for } \\
\text { small and medium enterprises (including grants and subsidies) }\end{array}$ & GEM \\
\hline
\end{tabular}


Table 3. Correlation matrix.

\begin{tabular}{|c|c|c|c|c|c|c|c|c|c|c|}
\hline & (1) & (2) & (3) & (4) & (5) & (6) & (7) & (8) & (9) & (10) \\
\hline (1) TEA & 1.00 & & & & & & & & & \\
\hline (2) TEA op & 0.948 & 1.00 & & & & & & & & \\
\hline (3) TEA nec & 0.292 & 0.119 & 1.00 & & & & & & & \\
\hline (4) GINI & -0.143 & -0.220 & 0.137 & 1.00 & & & & & & \\
\hline (5) Employment & 0.580 & 0.545 & 0.229 & -0.162 & 1.00 & & & & & \\
\hline (6) Part-time empl. & -0.04 & -0.087 & 0.153 & 0.184 & 0.162 & 1.00 & & & & \\
\hline (7) Unemploym. & -0.14 & -0.096 & -0.354 & 0.141 & -0.699 & -0.196 & 1.00 & & & \\
\hline (8) GDPpc & 0.549 & 0.521 & 0.118 & -0.169 & 0.732 & -0.025 & -0.644 & 1.00 & & \\
\hline (9) Pop.density & 0.097 & 0.180 & -0.141 & -0.023 & 0.067 & 0.019 & -0.016 & 0.033 & 1.00 & \\
\hline (10) Finsupport & 0.396 & 0.452 & -0.208 & -0.250 & 0.277 & -0.270 & 0.003 & 0.355 & 0.1376 & 1.00 \\
\hline
\end{tabular}

\subsubsection{Dependent Variables}

Models 1 and 2: The dependent variable in these models is total early-stage entrepreneurial activity (TEA), that is, the percentage of the population between 18 and 64 years old who are either in the process of starting a business (nascent entrepreneurs) or the owner-manager of a new business which is less than 42 months old [38].

Models 3 and 4: The dependent variable in these models is opportunity-driven entrepreneurship, measured as opportunity-driven TEA (TEA op), that is, the percentage of the population who are involved in an early-stage business (either as a nascent entrepreneur or an owner-manager of a new business) motivated by the recognition of an entrepreneurial opportunity [38].

Models 5 and 6 The dependent variable in these models is necessity-driven entrepreneurship, measured as necessity-driven TEA (TEA nec), that is, the percentage of the population who are involved in early-stage business (either as a nascent entrepreneur or an owner-manager of a new business) motivated by necessity [38].

\subsubsection{Predictor Variables}

In order to investigate the main effects of income inequality on entrepreneurial activity (TEA, TEA op and TEA nec), we adopted a proxy often used in the literature, namely the Gini index. The Gini index is a measure commonly used in longitudinal studies to assess the extent to which the distribution of income among individuals or households within an economy deviates from a perfectly equal distribution.

As mentioned in the introductory section, there is some evidence to relate some forms of entrepreneurship-specifically, self-employment-with increased income inequality. There is no evidence of such a relationship in the case of Spain, and to the best of our knowledge, none of the studies into the relationship between inequality and entrepreneurship considers the possibility of reverse causality. Moreover, we submitted the model to a Hausman test, which confirmed the absence of endogeneity. Nevertheless, we built an IV model using four lags of the Gini index as the instrumental variables. The results of Wu-Hausmann tests applied to these models confirmed the absence of endogeneity and the inappropriateness of IV models for this regression.

Financial support (Finsupport) was introduced in the model as an interaction term with the Gini index in order to capture the effect of income inequality contingent on different levels of financial support. Perceived financial support is traditionally positively related to entrepreneurial activity, although its effect on opportunity entrepreneurship is considered to be higher than the other forms of entrepreneurship.

In order to find the effect of demand during the crisis, two proxies were introduced: internal market openness (from GEM) and regional VAT income. No significant effect as predictor variables was found in either case, either directly or through interaction with Gini. 


\subsubsection{Control Variables}

The other variables in the models are regional-level control variables obtained from the Eurostat dataset. Because the GEM research suggests that labor market conditions constitute an important determinant of entrepreneurship, we also included various measures of the labor market, namely variations in the number of employed, unemployed and part-time workers. Unemployment and part-time employment traditionally relate to necessity entrepreneurship (Van der Zwan et al. 2016). We did not include variations in the active population, since to do so would have introduced endogeneity into the dataset, given its high correlation with employment.

The remaining regional control variables were GDPpc and population density. Both are used in studies of the determinants of entrepreneurship (e.g., [42] and [33], respectively). Further control variables that are used in the literature refer to the formal and informal institutional contexts, such as government effectiveness [5]. These control variables were considered but not included in this work due to limitations in data availability at the regional level.

\section{Results}

\subsection{Total Entrepreneurial Activity}

Table 4 presents the results of the regression analysis. All models are statistically significant and have a high explanatory capacity. We note that our results do not corroborate the view of others $[6,8]$ since, as shown by the standardized coefficients in all models, inequality has a negative and statistically significant $(p<0.05)$ effect on total entrepreneurial activity, thus providing empirical support for H1.

The interaction term used to introduce the effect of financial support in the relationship between entrepreneurship and inequality has a positive and statistically significant effect, with a value almost the same as that of inequality.

Other important results come from the relationship between entrepreneurial activity and labor market characteristics. The variations in the number of employed people significantly explain entrepreneurial activity and the relationship is positive. By contrast, increases in part-time employment negatively affect TEA, although it is not statistically significant in any model. Finally, there is a positive and statistically significant relationship between unemployment and total entrepreneurial activity. Neither GDPpc nor population density is statistically significant.

Table 4. Results of linear regressions models.

\begin{tabular}{|c|c|c|c|c|c|c|c|c|c|}
\hline \multirow{2}{*}{$\begin{array}{c}\begin{array}{c}\text { Dependent } \\
\text { Variable }\end{array} \\
\text { Model } \\
\end{array}$} & \multicolumn{3}{|c|}{$\begin{array}{l}\text { Total Entrepreneurial } \\
\text { Activity (H1) }\end{array}$} & \multicolumn{3}{|c|}{$\begin{array}{l}\text { Oportunity Entrepreneurship } \\
\text { (H2) }\end{array}$} & \multicolumn{3}{|c|}{$\begin{array}{l}\text { Necessity Entrepreneurship } \\
\text { (H3) }\end{array}$} \\
\hline & (1) & (2) & (3) & (3) & (4) & (3) & (5) & (6) & (3) \\
\hline $\begin{array}{l}\text { Income inequality } \\
\text { (Gini Index) }\end{array}$ & $\begin{array}{c}-0.471 \\
(0.201) \\
* *\end{array}$ & $\begin{array}{c}-0.438 \\
* * \\
(0.203)\end{array}$ & $\begin{array}{c}-0.431 \\
* * \\
(0.034)\end{array}$ & $\begin{array}{c}-0.403 \\
* * \\
(0.173)\end{array}$ & $\begin{array}{c}-0.381 \\
* * \\
(0.175)\end{array}$ & $\begin{array}{c}-0.390 \\
* * \\
(0.178)\end{array}$ & $\begin{array}{l}-0.017 \\
(0.056)\end{array}$ & $\begin{array}{l}-0.018 \\
(0.055)\end{array}$ & $\begin{array}{l}-0.007 \\
(0.058)\end{array}$ \\
\hline Unemployment & $\begin{array}{l}0.853^{* * *} \\
(0.181)\end{array}$ & $\begin{array}{l}0.716^{* * *} \\
(0.257)\end{array}$ & $\begin{array}{l}0.574^{* * *} \\
(0.261)\end{array}$ & $\begin{array}{l}0.793 * * * \\
(0.157)\end{array}$ & $\begin{array}{l}0.706^{* *} \\
(0.221)\end{array}$ & $\begin{array}{l}0.609 * * \\
(0.229)\end{array}$ & $\begin{array}{l}0.171^{* * *} \\
(0.050)\end{array}$ & $\begin{array}{c}0.168^{* * *} \\
(0.073)\end{array}$ & $\begin{array}{l}0.217^{* * *} \\
(0.0075)\end{array}$ \\
\hline Employment & $\begin{array}{c}0.708^{* * *} \\
(0.191)\end{array}$ & $\begin{array}{l}0.490^{* * *} \\
(0.314)\end{array}$ & $\begin{array}{c}0.253 * * * \\
(0.319)\end{array}$ & $\begin{array}{c}0.446^{* * *} \\
(0.164)\end{array}$ & $\begin{array}{c}0.130 * * * \\
(0.270)\end{array}$ & $\begin{array}{c}0.121^{* * *} \\
(0.291)\end{array}$ & $\begin{array}{l}-0.033 \\
(0.054)\end{array}$ & $\begin{array}{c}0.030 \\
(0.093)\end{array}$ & $\begin{array}{l}-0.094 \\
(0.009)\end{array}$ \\
\hline $\begin{array}{l}\text { Part-time } \\
\text { employment }\end{array}$ & $\begin{array}{l}-0.120 \\
(0.160)\end{array}$ & $\begin{array}{l}-0.111 \\
(0.162)\end{array}$ & $\begin{array}{c}0.023 \\
(0.163)\end{array}$ & $\begin{array}{l}-0.133 \\
(0.138)\end{array}$ & $\begin{array}{l}-0.131 \\
(0.139)\end{array}$ & $\begin{array}{c}0.049 \\
(0.143)\end{array}$ & $\begin{array}{c}0.024 \\
(0.044)\end{array}$ & $\begin{array}{c}0.024 \\
(0.046)\end{array}$ & $\begin{array}{c}0.029 \\
(0.047)\end{array}$ \\
\hline GDPpc & & $\begin{array}{c}0.001 \\
(4.496)\end{array}$ & $\begin{array}{c}0.001 \\
(0.001)\end{array}$ & & $\begin{array}{c}0.001 \\
(0.001)\end{array}$ & $\begin{array}{c}0.001 \\
(0.001)\end{array}$ & & $\begin{array}{l}-0.001 \\
(0.001)\end{array}$ & $\begin{array}{c}0.001 \\
(0.001)\end{array}$ \\
\hline Population density & & $\begin{array}{c}0.113 \\
(7.969)\end{array}$ & $\begin{array}{c}0.113 \\
(7.835)\end{array}$ & & $\begin{array}{l}-0.106 \\
(6.870)\end{array}$ & $\begin{array}{l}-0.104 \\
(6.859)\end{array}$ & & $\begin{array}{l}-0.090 \\
(2.273)\end{array}$ & $\begin{array}{c}0.489 \\
(2.260)\end{array}$ \\
\hline Gini * Finsupport & & & $\begin{array}{l}0.406^{* *} \\
(0.194)\end{array}$ & & & $\begin{array}{l}0.381^{* *} \\
(0.169)\end{array}$ & & & $\begin{array}{c}0.005 \\
(0.055)\end{array}$ \\
\hline
\end{tabular}


Table 4. Cont.

\begin{tabular}{|c|c|c|c|c|c|c|c|c|c|}
\hline \multirow{2}{*}{$\begin{array}{c}\text { Dependent } \\
\text { Variable }\end{array}$} & \multicolumn{3}{|c|}{$\begin{array}{l}\text { Total Entrepreneurial } \\
\text { Activity (H1) }\end{array}$} & \multicolumn{3}{|c|}{$\begin{array}{l}\text { Oportunity Entrepreneurship } \\
\text { (H2) }\end{array}$} & \multicolumn{3}{|c|}{$\begin{array}{c}\text { Necessity Entrepreneurship } \\
\text { (H3) }\end{array}$} \\
\hline & (1) & (2) & (3) & (3) & (4) & (3) & (5) & (6) & (3) \\
\hline $\begin{array}{l}\text { F test for joint } \\
\text { significance } \\
(p \text {-value })\end{array}$ & $\begin{array}{c}1.584 \times \\
10^{-12}\end{array}$ & $\begin{array}{c}1.197 \times \\
10^{-11}\end{array}$ & $\begin{array}{c}3.377 \times \\
10^{-10}\end{array}$ & $\begin{array}{c}5.278 \times \\
10^{-12}\end{array}$ & $\begin{array}{c}3.541 \times \\
10^{-11}\end{array}$ & $\begin{array}{c}1.469 \times \\
10^{-10}\end{array}$ & 0.001 & 0.006 & 0.010 \\
\hline $\mathrm{R} 2$ & 0.610 & 0.626 & 0.644 & 0.595 & 0.612 & 0.623 & 0.244 & 0.244 & 0.277 \\
\hline Adjusted R2 & 0.489 & 0.493 & 0.493 & 0.469 & 0.475 & 0.463 & 0.007 & -0.024 & -0.030 \\
\hline
\end{tabular}

\subsection{Opportunity-Driven Entrepreneurial Activity}

All models are statistically significant and have a high explanatory capacity. Again, our results do not corroborate the view of others $[6,8]$ since, as shown by the standardized coefficients in all models, inequality has a negative and statistically significant $(p<0.05)$ effect in Models 3 and 4 , thus providing empirical support for $\mathrm{H} 2$. The size of the effect is slightly lower than that of total entrepreneurial activity, but similar. Likewise, the interaction term used to introduce the effect of financial support in the relationship between opportunity entrepreneurship and inequality has a positive and statistically significant effect, with a value almost the same as that of inequality. With regard to opportunity-driven entrepreneurial activity and labor market characteristics, the relationship is similar to that of total entrepreneurial activity. The variation in the number of employed people has a significant and positive affect on opportunity entrepreneurship. By contrast, increases in part-time employment negatively affect opportunity-driven entrepreneurship, although this is not statistically significant in the model. Finally, there is a positive and statistically significant relationship between unemployment and opportunity entrepreneurship. Neither GDPpc nor population density is statistically significant.

\subsection{Necessity-Driven Entrepreneurial Activity}

The explanatory capacity of the models is low compared to those for total and opportunity-driven entrepreneurship. Inequality, which is not statistically significant, has a negative effect on necessity-driven entrepreneurial activity, although the explanatory capacity of the model is very low ( $\mathrm{R} 2<0.1)$, meaning that this relationship (H3) remains inconclusive. Regarding the relationship between necessity-driven entrepreneurial activity and the control variables, there is a positive relationship between unemployment and necessity-driven entrepreneurship, while the remaining variables are not statistically significant.

\section{Discussion}

The results indicate that income inequality, measured in terms of the Gini index, has a significant impact on total and opportunity-driven entrepreneurial activity. However, the relationships are negative, which confirms our hypotheses (with the exception of $\mathrm{H} 3$ ), in contrast to the theoretical and empirical evidence found in the literature $[6,8]$.

The main difference between our analysis and the empirical studies reported in the literature is that we focus on a crisis period, namely, the Great Recession in Spain, when the economy across all regions was affected by rising rates of unemployment and increasing poverty. In this context, higher levels of inequality may drastically reduce the financial resources for a large share of the population, who are then forced to rely more on their own equity to set up a business [7].

In these circumstances, given that a minimum financial investment is necessary for starting a business, especially in opportunity driven entrepreneurship, the inability to access bank credit and an unwillingness to invest one's own resources would deter potential entrepreneurs from pursuing entrepreneurial opportunities. The coefficients of the relationship between inequality and 
entrepreneurial activity are lower for total $(-0.431)$ and opportunity-driven entrepreneurial activity $(-0.390)$ compared to necessity entrepreneurship $(-0.007)$, suggesting that financial resources are a more influential factor in opportunity-driven than in necessity-driven entrepreneurship [8,36].

This is confirmed with the inclusion of the interaction term in the model. The inclusion of financial support indicates that when perceived financial support is positive-that is, when potential entrepreneurs consider that there is an improvement in the financial instruments that can support the creation of businesses-its influence is high enough to convert the negative relationship between inequality and entrepreneurship into a positive one. Then, in a context of positive financial support, there would be a positive relationship between inequality and entrepreneurship, as is claimed in the literature [6,8]. This result is consistent with the view that financial constraints explain the negative relationship between inequality and entrepreneurship [7], and we consider it to be the key element that could reconcile both perspectives on inequality.

An additional effect could be that some potential entrepreneurs, especially necessity-driven ones, given their incapacity to face the minimum financial requirements to begin a business, could find themselves pushed to form part of the informal economy. This might reconcile the recession-push effect evidenced in the literature and the pro-cyclical evolution of entrepreneurial activity experienced during the last recession. Nevertheless, given the characteristics of the informal economy, this factor is difficult to measure and is not a goal of this paper.

Hence, the most important contribution of this work concerns the relationship between economic inequality and entrepreneurship in a downturn. The results indicate that, in contrast to one branch of the literature, the relationship between inequality and entrepreneurship is negative in a context of severe economic recession, as occurred throughout the regions of Spain over the period studied, and this negative relationship might be related to the effect of financial constraints.

Moreover, although it is not a goal of this paper, our results also show how labor market indicators impact both total and opportunity-driven entrepreneurial activity, confirming the theoretical background, which traditionally considers unemployment as a push factor by lowering the opportunity costs of self-employment, and thereby driving individuals to start their own business. Its economic effect is higher than the effect of inequality, which confirms its importance as push factor for entrepreneurship. To this end, entrepreneurship is frequently chosen as a solution for individuals' unemployment and uncertainty in the labor market [27,43-45]. Employment is also positively correlated with entrepreneurial activity and its size is the highest, even higher than unemployment; this can be explained by the fact that employment increases human capital and access to finance, which are positively correlated with both general and opportunity-driven entrepreneurial activity [8] (In this case the substitution effect between employment and entrepreneurship cannot be considered since we used regional-level aggregated data. Moreover, there is the effect of activity rate, which is not analyzed in this paper since it would have introduced endogeneity into the dataset, given its high correlation with employment.).

Nevertheless, our results show that part-time employment negatively affects entrepreneurial activity although it is not statistically significant. While voluntary part-time employment can be associated to higher rates of self-employment, involuntary employment — which rose during the Great Recession in Spain [35]—can result in the opposite effect. Thus, part-time employment does not increase financial endowments availability for creating a business while can mitigate the "escape for unemployment" effect. Then, there can be a substitute effect between part-time employment and entrepreneurial activity although it is not confirmed in the results.

\section{Conclusions}

The article addresses an under-researched area of entrepreneurship, namely, the relationship between income inequality and entrepreneurial activity. Our contribution to the field of study is twofold. First, the results of our analysis offer new empirical evidence about the effects of growing inequality on entrepreneurial activity, and show important differences compared to the results obtained 
in the scant existing literature. In this context, we find a negative relationship between inequality and general and opportunity-based entrepreneurship. Our results also show that this relationship becomes positive when financial support is introduced into the model. These results can be accounted for by the severe economic recession and credit crunch, in which increasing inequality can drastically reduce the financial resources for a large share of the population, preventing them from engaging in entrepreneurial activity and ultimately forcing them into the informal economy.

Second, our paper contributes to the literature by providing novel insights into the relationship between inequality and general and opportunity-based entrepreneurial activity in a context of economic downturn, which has not been addressed before.

Finally, we recognise certain limitations to the paper. The most important of these is that the results might be very context-dependent, since the sample is restricted to the regions constituting Spain and to the period 2007-2013. The influence of the Great Recession in Spain during this time led to a very particular economic situation, with a rapid deterioration in labor market conditions and the socio-economic context in general. Further empirical analysis of the relationship between income inequality and entrepreneurship in both recessionary and non-recessionary contexts would help to improve our knowledge.

The other limitation is that the paper focuses solely on the effects of inequality on entrepreneurship. As stressed in the introduction, this is a complex relationship in which reverse causality has also been evidenced, although the tests conducted on our models show no endogeneity. Indeed, some authors [13] shows that entrepreneurship may also contribute to economic inequality while others [12] suggest that entrepreneurship can contribute to enhancing economic prosperity by reducing inequality. Further empirical research should be conducted into the relationship between income inequality and entrepreneurship in order to fully understand its complexities. This could shed light on the role played by the informal economy and might reconcile the recession-push effect evidenced in the literature and the pro-cyclical evolution of entrepreneurial activity experienced during the last recession. This would be especially interesting given the scarcity of empirical studies in the literature. We hope that this paper has made some contribution towards this aim.

Author Contributions: Conceptualization, M.-T.A. and M.A.d.P.-B.; methodology, M.-T.A. and C.S.-L.; software, M.-T.A.; validation, M.-T.A., C.S.-L. and M.A.d.P.-B.; formal analysis, M.-T.A. and C.S.-L.; investigation, M.-T.A.; resources, M.-T.A.; data curation, M.T.A.; writing—original draft preparation, M.-T.A.; writing—review and editing, M.-T.A., C.S.-L. and M.A.d.P.-B. All authors have read and agreed to the published version of the manuscript.

Funding: This research received no external funding.

Conflicts of Interest: The authors declare no conflict of interest.

\section{References}

1. Atkinson, A.; Piketty, T.; Saez, E. Top Incomes in the Long Run of History. J. Econ. Lit. 2011, 49, 3-71. [CrossRef]

2. Cingano, F. Trends in Income Inequality and its Impact on Economic Growth. In OECD Social, Employment and Migration Working Papers; No. 163; OECD Publishing: Paris, France, 2014. [CrossRef]

3. Sánchez, C.; de Paz, M.A. Desigualdad y pobreza en la Gran Recesión. Diferencias entre los países de la UE. Rev. Econ. Mund. 2016, 44, 93-124.

4. Stephan, U.; Uhlaner, L.M.; Stride, C. Institutions and Social Entrepreneurship: The Role of Institutional Voids, Institutional Support, and Institutional Configurations. J. Int. Bus. Stud. 2014, 46, 308-331. [CrossRef]

5. Pathak, S.; Muralidharan, E. Informal Institutions and Their Comparative Influences on Social and Commercial Entrepreneurship: The Role of In-Group Collectivism and Internpersonal Trust. J. Small Bus. Manag. 2016, 54, 168-188. [CrossRef]

6. Lippmann, S.; Davis, A.; Aldrich, H.E. Entrepreneurship and Inequality. Res. Sociol. Work. 2005, 15, 3-31. [CrossRef] 
7. Braggion, F.; Dwarkasing, M.; Ongena, S. Household wealth inequality, entrepreneurs' financial constraints, and the great recession: Evidence from the Kauffman Firm Survey. Small Bus. Econ. 2018, 50, 533-543. [CrossRef]

8. Xavier-Oliveira, E.; Laplume, A.O.; Pathak, S. What motivates entrepreneurial entry under economic inequality? the role of human and financial capital. Hum. Relat. 2015, 68, 1183-1207. [CrossRef]

9. Ragoubi, H.; El Harbi, S. Entrepreneurship and income inequality: A Spatial panel data analysis. Int. Rev. Appl. Econ. 2018, 32, 374-422. [CrossRef]

10. Pathak, S.; Muralidharan, E. Economic Inequality and Social Entrepreneurship. Bus. Soc. 2018, 57, 1150-1190. [CrossRef]

11. Bapuji, H.; Neville, L. Income inequality ignored? an agenda for business and strategic organization. Strateg. Organ. 2015, 13, 233-246. [CrossRef]

12. Apetrei, A.; Sánchez-García, J.L.; Sapena, J. The controversial link between entrepreneurial activity and inequality. Int. Entrep. Manag. J. 2019, 15, 485-502. [CrossRef]

13. Halvarsson, D.; Korpi, M.; Wennberg, K. Entrepreneurship and income inequality. J. Econ. Behav. Organ. 2018, 145, 275-293. [CrossRef]

14. Lewellyn, K.B. Income inequality, entrepreneurial activity and National Business Systems: A configurational analysis. Bus. Soc. 2018, 57, 1114-1149. [CrossRef]

15. Atems, B.; Shand, G. An empirical analysis of the relationship between entrepreneurship and income inequality. Small Bus. Econ. 2018, 51, 905-922. [CrossRef]

16. Kerr, W.R.; Nanda, R. Financing constraints and entrepreneurship. In Handbook of Research on Innovation and Entrepreneurship; Audretsch, D., Heblich, S., Eds.; National Bureau of Economic Research: Cambridge, UK, 2011; pp. 88-103.

17. Liñán, F.; Fernández-Serrano, J.; Romero, I. Necessity and opportunity entrepreneurship: The mediating effect of culture. [Emprendimiento por necesidad y por oportunidad: El efecto mediador de la cultura]. Rev. Econ. Mund. 2013, 33, 21-47.

18. Nabi, G.; Liñán, F. Considering business start-up in recession time: The role of risk perception and economic context in shaping the entrepreneurial intention. Int. J. Entrep. Behav. Res. 2013, 19, 633-655. [CrossRef]

19. Arrighetti, A.; Caricati, L.; Landini, F.; Monacelli, N. Entrepreneurial intention in the time of crisis: A field study. Int. J. Entrep. Behav. Res. 2016, 22, 835-859. [CrossRef]

20. Simón-Moya, V.; Revuelto-Taboada, L.; Ribeiro-Soriano, D. Influence of economic crisis on new SME survival: Reality or fiction? Entrep. Reg. Dev. 2016, 28, 157-176. [CrossRef]

21. Devece, C.; Peris-Ortiz, M.; Rueda-Armengot, C. Entrepreneurship during economic crisis: Success factors and paths to failure. J. Bus. Res. 2016, 69, 5366-5370. [CrossRef]

22. Tsilika, T.; Kakouris, A.; Apostolopoulos, N.; Dermatis, Z. Entrepreneurial bricolage in the aftermath of a shock. Insights from Greek SMEs. J. Small Bus. Entrep. 2020, 1-18. [CrossRef]

23. Papaoikonomou, E.; Segarra, P.; Li, X. Entrepreneurship in the context of crisis: Identifying barriers and proposing strategies. Int. Adv. Econ. Res. 2012, 18, 111-119. [CrossRef]

24. Apostolopoulos, N.; Newbery, R.; Gkartzios, M. Social enterprise and community resilience: Examining a Greek response to turbulent times. J. Rural Stud. 2019, 70, 215-224. [CrossRef]

25. Corak, M. Income Inequality, Equality of Opportunity, and Intergenerational Mobility. J. Econ. Perspect. 2013, 27, 79-102. [CrossRef]

26. Reynolds, P.D.; Bygrave, W.D.; Autio, E.; Cox, L.W.; Hay, M. Global Entrepreneurship Monitor 2002(2003) Executive Report; GEM: London, UK, 2003.

27. Van der Zwan, P.; Thurik, R.; Verheul, I.; Hessels, J. Factors influencing the entrepreneurial engagement of opportunity and necessity entrepreneurs. Eurasian Bus. Rev. 2016, 6, 273-295. [CrossRef]

28. Davidsson, P.; Recker, J.; von Briel, F. External Enablement of New Venture Creation: A Framework. Acad. Manag. Perspect. 2018, in press. [CrossRef]

29. Fairlie, R.W. Entrepreneurship, economic conditions, and the great recession. J. Econ. Manag. Strategy 2013, 22, 207-231. [CrossRef]

30. Gabe, T.M.; Florida, R. Effects of the housing boom and bust on U.S. metro employment. Growth Chang. 2013, 44, 391-414. [CrossRef]

31. Martin, R. Regional economic resilience, hysteresis and recessionary shocks. J. Econ. Geogr. 2012, 12, 1-32. [CrossRef] 
32. Obschonka, M.; Stuetzer, M.; Audretsch, D.B.; Rentfrow, P.J.; Potter, J.; Gosling, S.D. Macro-Psychological Factors Predict Regional Economic Resilience during A Major Economic Crisis. Soc. Psychol. Personal. Sci. 2016, 7, 95-104. [CrossRef]

33. González-Pernía, J.L.; Guerrero, M.; Jung, A.; Peña-Legazkue. Economic recession shake-out and entrepreneurship: Evidence from Spain. BRQ Bus. Res. Q. 2018, 21, 153-167. [CrossRef]

34. Vegetti, F.; Adascalitei, D. The impact of the economic crisis on latent and early entrepreneuship in Europe. Int. Entrep. Manag. J. 2017, 13, 1289-1314. [CrossRef]

35. Gradín, C. Why is income inequality so high in Spain? Res. Labor Econ. 2016, 44, 109-177.

36. Stephan, U.; Hart, M.; Drews, C.C. Understanding Motivations for Entrepreneurship: A Review of Recent Research Evidence; Enterprise Research Centre and Aston Business School, Aston University: Birmingham, UK, 2015.

37. Jurado, A.; Pérez, J. Disparidades Entre las Comunidades Autónomas Españolas en el Período 2007-2012, VII Informe Sobre Exclusión y Desarrollo Social en España; Fundación FOESSA: Madrid, Spain, 2014.

38. GEM. España. Informe GEM España 2017; GEM: Madrid, Spain, 2018.

39. Croissant, Y.; Millo, G. Panel Data Econometrics in R: The PLM package. J. Stat. Softw. 2008, $27,1-43$. [CrossRef]

40. Arellano, M.; Bond, S.R. Some Tests of Specification for Panel Data: Monte Carlo Evidence and an Application to Employment Equations. Rev. Econ. Stud. 1991, 58, 277-297. [CrossRef]

41. Montero, R. Efectos Fijos o Aleatorios: Test de Especificación; Documentos de trabajo de Economía Aplicada, Universidad de Granada: Granada, Spain, 2011.

42. Albulescu, C.T.; Tamaçila, M. The impact of FDI on entrepreneurship in the European Countries. Procedia Soc. Behav. Sci. 2014, 124, 219-228. [CrossRef]

43. Evans, D.S.; Leighton, L.S. Small business formation by unemployed and employed workers. Small Bus. Econ. 1990, 2, 319-330. [CrossRef]

44. Parker, S.C. The Economics of Entrepreneurship; Cambridge University Press: Cambridge, UK, 2009. [CrossRef]

45. Rocha, V.; Carneiro, A.; Varum, C.A. Entry and exit dynamics of nascent business owners. Small Bus. Econ. 2015, 45, 63-84. [CrossRef]

(C) 2020 by the authors. Licensee MDPI, Basel, Switzerland. This article is an open access article distributed under the terms and conditions of the Creative Commons Attribution (CC BY) license (http://creativecommons.org/licenses/by/4.0/). 